\title{
Young Businesspeople's Entrepreneurial Perceptions and Intentions to Contribute to Local Communities: A Case Study of the Cultured Pearl Industry in Mie, Japan
}

\author{
$\underline{\text { Max Weeks }}{ }^{1}$, Hiroko Oe ${ }^{2 *}$, Yasuyuki Yamaoka ${ }^{3}$, Takuya Hirata ${ }^{4}$ \\ ${ }^{1}$ Brockenhurst College, UK \\ ${ }^{2}$ The Business School, Bournemouth University, UK \\ ${ }^{3}$ The Open University of Japan \\ ${ }^{4}$ Yokohama National University, Japan \\ Email: hoe@bournemouth.ac.uk, yamaoka-y@ouj.ac.jp
}

\section{Abstract:}

A number of theoretical frameworks attempt to help those in disadvantaged areas by encouraging growth in local industries created in those areas. However, as far as the authors are aware, not all of these attempts have been successful. The case discussed here is that of the cultured pearl industry, a traditional Japanese industry. In particular, the research focuses on the cultured pearl industry in Mie Prefecture, located in the western part of Mainland Japan, and the attitudes of young entrepreneurs who aim to support its sustainable development. A quantitative approach was applied to survey data collected from 170 respondents living in and originating from Mie Prefecture, through which this research attempts to identify the factors motivating young entrepreneurs to contribute to the industrial revitalisation of their local communities. Four potential motivating factors for young entrepreneurs to contribute to their local communities were initially hypothesised (sense of community involvement, attachment to community, economic value, and non-economic value, such as that related to community ties). These were then analysed and examined based on a factor analysis and regression model. The analytical results indicated that three of the four factors were significant in estimating the willingness of young entrepreneurs to contribute to the community, with the exception being the third factor, 'economic value'. This finding may not be immediately generalisable due to the small amount of data available for the study and the need to compare individual respondent demographics and response trends. For example, it may be that the participants in this survey were already successful entrepreneurs with no financial concerns and a desire to contribute to the local pearl businesses and community development in addition to their primary businesses. Thus, a future research goal is to evaluate the results of this study through a detailed survey that considers the respondents' individual attributes. However, as a pilot test, this study indicates that the young generation, with its entrepreneurial spirit, does not necessarily have economic value as their primary goal. Instead, they may be more attentive to sociocultural factors; in particular, they may be prepared to take a stand for the sustainable development of their local communities.

Keywords:

community; sustainable local business; entrepreneurship; cultured pearl businesses; noneconomic value; Japan

\section{Introduction}

\subsection{Background of the Study}

Not only has the recent pollution of seawater been affecting pearl production, but the lack of a marketing strategy and a functional value chain has also resulted in an increasingly 


\section{Economit Journal: Scientific Journal of Accountancy, Management and Finance ISSN: 2775-5827 (Online), 2775-5819 (Print)}

Vol. 1, No. 2, May 2021, Page: 96-109

Email: economitjournal@gmail.com

challenging situation in the cultured pearl industry. This study discusses how to rescue and realise sustainable community business in the seashore family-based business value chain and the associated communities themselves.

Up to this day, the main consumers of pearls have always been women. However, surprisingly, pearl producers have never paid attention to their voices in the market. In addition, the processes involved in the production-to-sales line are disconnected from one another, meaning stakeholders lack an information exchange route. This fact appears to lead to a situation in which market information is not filtered back to the seaside, where the pearl culturing takes place. Further, those within the industry do not have a good understanding of marketing.

To tackle this situation in the industry, this study was divided into three phases: (1) state the problems that will be discussed in this study; (2) extract academic implications from a literature review of interdisciplinary entrepreneurship, leadership, and social capital and construct hypotheses to be verified; (3) test those hypotheses with a survey dataset collected from young entrepreneurs in the relevant area, Mie, Japan; (4) discuss the conclusions of the research, and future recommendations are presented.

\subsection{Research Rationale}

Cultured pearls, which are one of Japan's greatest inventions, have seen a decline in production year on year, while it has remained unclear how to deal with the proliferation of South Sea pearls (SSPs) in other regions and the lack of detailed data collection and accumulation due to government reforms. In addition, due to the effects of the Great East Japan Earthquake of 11 March 2011, the focus of national and local government fishery policy has shifted to recovery from the disaster, measures to deal with contaminated water from the Fukushima nuclear power plant accident and ensuring the safety of fishery resources. The dominance of cultured pearls has thus been in decline, all the way up to the present day (Oe \& Yamaoka, 2013).

The statistical data surrounding the production of Akoya pearls and recent market trends are discussed in detail in Chapter 2, which summarises the research perspectives that form this study's focus. It is recognised that the production of cultured pearls is currently stagnant. It is also understood that there is a problem of business succession in the areas that support the pearl industry. There is a gap in perception between awareness of those responsible for the production and the market for pearl products sold as luxury goods. There is also a lack of research on the factors and mechanisms that stimulate young entrepreneurs who are motivated to take over businesses and, through these businesses, revitalise and contribute to the local economy and society (Oe \& Yamaoka, 2013).

This study intends to help the cultured pearl industry in local coastal village businesses understand what motivates and drives young entrepreneurs into the traditional cultural pearl industry and develop attitudes and marketing strategies that contribute to sustainable cultured pearl production. 


\section{Review of Literatures}

\subsection{Historical Data and Discussion Points}

Pearls are some of the most beautiful gemstones in the world. While their organic constituent compounds are found naturally in the earth's crust, they are created by living organisms, meaning they are categorised as organic gemstones. The finest quality loose pearls have been highly valued as gemstones and objects of beauty for many centuries, and the word pearl has become a metaphor for something rare, fine, admirable, pure or beautiful.

Pearl culturing technology was invented in Japan, and the industry supporting it has a history of over 100 years. Japan has thus been a central platform for pearl dealers and pearl design, and it has played a central role in the pearl industry worldwide. However, currently, the industry is seeing a remarkable decline in volume and quality, to the point that it is no longer considered viable to leave the situation.

Figure 1 shows the total cultured saltwater pearl production and the changes in the ratio among Akoya, white-lip, and black-lip pearls. The figure shows a noticeable decline in Akoya pearls, whose production ratio has become remarkably low. Figure 2 demonstrates the same trend in pearl production, further indicating this decline. Due to the restructuring of the Japanese government about fisheries, statistical data can only be obtained up to the year 2009, though data from this time had already begun to indicate the massive decline in products based on Japanese Akoya pearls.

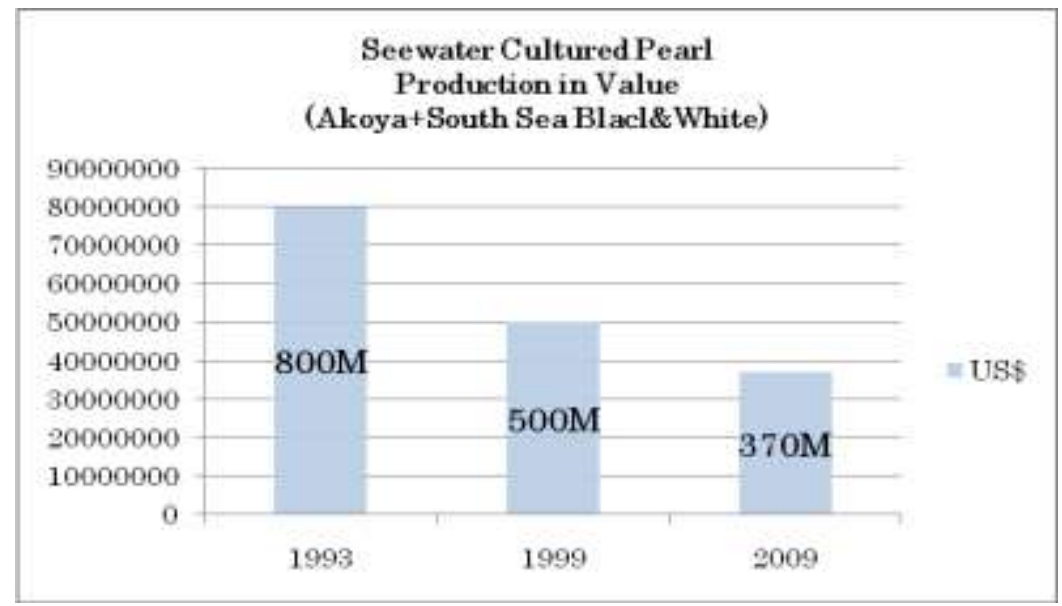

Figure 1. Cultured Seawater Pearl Production in Value

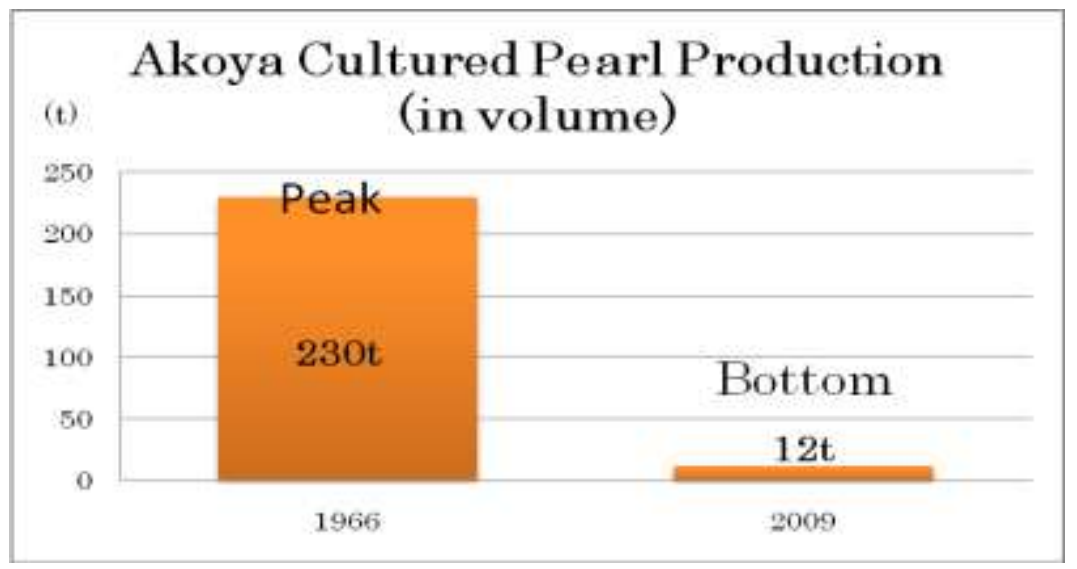

Figure 2. Akoya Cultured Pearl Production (Peak and Bottom) 
At the same time, Figure 3 indicates that there was a tremendous increase in both the weight and value of black SSPs. Similarly, Figure 4 shows the trend in white SSP production, which was only slightly different from that of black SSPs. The market demand for white SSPs is still healthily increasing, and their value is following the same trend, according to market mechanisms.

There have been significant changes in the weights and prices of various pearls, which, without a doubt, must have had a substantial impact on the Japanese pearl industry. The decline in Akoya production requires serious shifts in marketing strategy and the production of Akoya pearls in Japan. The Japanese pearl industry, which had enjoyed rapid growth after the close of World War II, began to suffer from severe depression starting in 1966. It is considered that this depression was mainly caused by foreign buyers of pearl, who sharply cut down on the amount of pearls they purchased. They did so because they had an excess of stock-in-trade at the time, and this naturally resulted in a sharp decrease in the price of the Japanese cultured pearls. In particular, the price went down by 30\% in 1967 as compared with the previous year. From 1966 to 1971, extensive efforts were made by governmental agencies to reduce the production to one half of its previous amount and to control the price by means of stocking in response to overproduction (Japan Fisheries Agency, 2017).

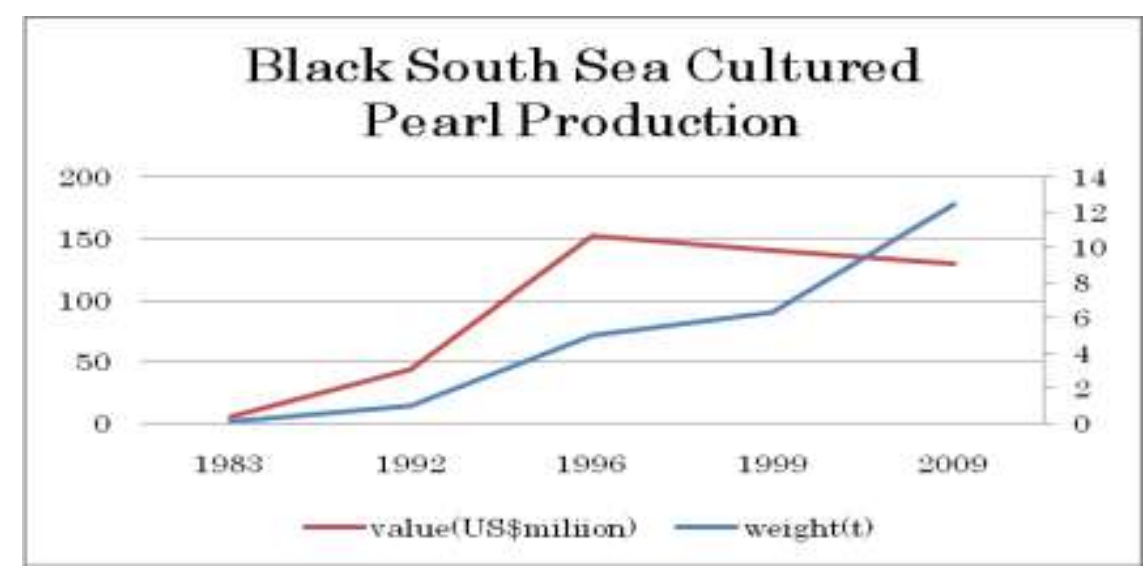

Figure 3. Volume and Weight of Black Cultured SSPS

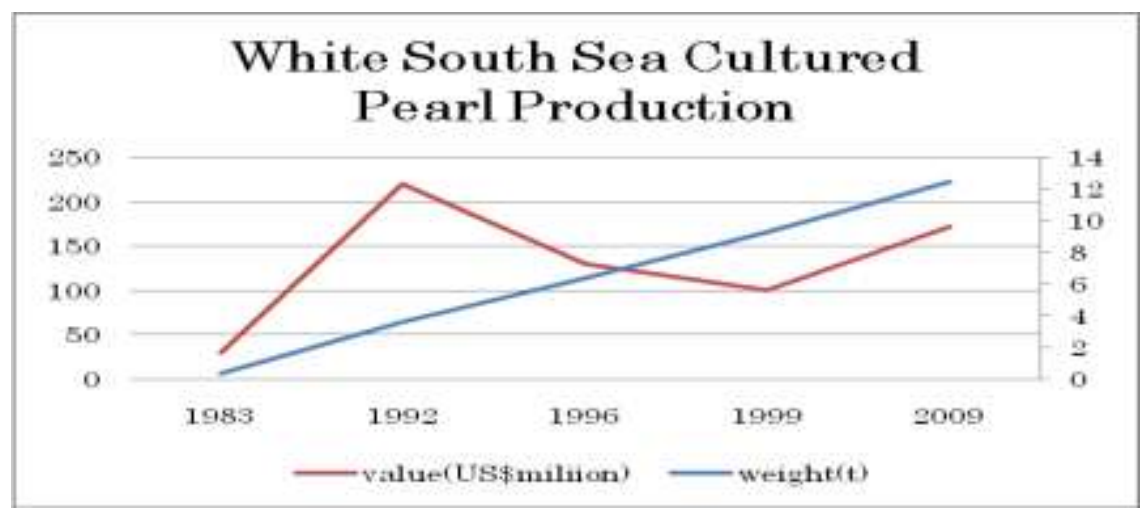

Figure 4. Volume and Weight of White Cultured SSPs

\subsection{Entrepreneurship and Its Orientation to Support Local Business \\ a. Corporate Entrepreneurship}

Biniari (2012) suggested that researchers need to distinguish between the influence of environmental factors and that of factors internal to the organisation. Researchers should especially pay attention to the impacts interorganisational alliances have on the 
entrepreneurship of organisations. Further, it has been emphasised that knowledge acquisition based on alliances can affect the relationship between corporate entrepreneurship and performance. Eddleston et al. (2012) drew from a theory of stewardship, claiming that corporate entrepreneurship, especially that in smaller enterprises, such as family firms, is inclined towards institutional culture. Therefore, there should be a focus on comprehensive strategic decision-making regarding how to achieve entrepreneurial practices from a longerterm perspective. Fini et al. (2012) studied the determinants of corporate entrepreneurial intention (CEI) within small and newly established firms, pointing out that entrepreneurial activities usually occur due to individuals' behaviours. They also claim that the CEIs of the founders are crucial to explaining these companies' abilities as new start-ups. They imply that CEI and engagement in entrepreneurial action are influenced by specific motivation, individual skills, and perceived environmental dynamism. Based on this insight, specific individuals with motivation and skills can trigger the enhancement of business potential.

Gemmell et al. (2012) analysed how entrepreneurs obtain the creative ideas they need to develop innovative new products, insisting that a complex, cyclical and recursive multilevel social process can nurture an entrepreneurial culture within organisations. In addition, they suggest that active and social experimentation may have a significant impact on organisational learning. In line with this discussion of CEI, Oe \& Yamaoka (2013) stated that a catalyst for enhancing interaction among the relevant stakeholders is critical for encouraging innovative entrepreneurial activities. In addition, in a challenging environment, such as that brought about by COVID-19, socially innovative mindsets and ubiquitous networks among communities should be the basis for a collaborative business orientation (Oe \& Weeks, 2020).

\section{b. Entrepreneurial Proactiveness and Knowledge-Based Innovation}

Haynie et al. (2012) argued that sensing and adapting to uncertainty by leveraging prior entrepreneurial knowledge is a critical ability. Insights into the interplay among knowledge, learning, and cognition common to other industries' actions and activities can also be exercised among relevant local business stakeholders. In other words, this process should be designed and provided to the potential workforce as a platform to nurture a robust and innovative local business environment. Kreiser (2011) also investigated how entrepreneurial orientation (EO) plays a role in enhancing an organisation's level of acquisitive and experimental learning. He develops propositions concerning a firm's ability to link itself to disparate sources of knowledge directly. Network participation is crucial so as to maximise levels of organisational learning while conserving limited resources. This implies that EO can bring strong and high-quality social capital into an organisation, which is essential for organisational learning, especially in a disruptive environment.

Lordkipanidze et al. (2005) argued that entrepreneurship is a central force in economic development because it brings growth and acts as a vehicle for innovation and change. Further, Morris et al. (2012) emphasised the importance of 'lived experience' and the learning process in making companies more innovative. (2012). The unique characteristics of the entrepreneurial experience can provide a solid basis for innovative business performance, but how to link experience to economic impact has not been discussed, and methods for measuring this have not yet been proposed. According to these findings, the diverse actors among a community should be defined as assets that enhance the community's entrepreneurial spirit through their enterprising spirit and practices to support sustainable business. However, as it stands, this is not sufficient to trigger the revitalisation of local communities. It thus needs to be asked what further schemes and catalysts are needed. To answer this question, a discussion of social capital will be helpful. In addition, though this study assumes young entrepreneurs will initiate such community revitalisation, there is a lack of research on the 
factors that bring about a call to action for such young entrepreneurs, who are the next generation of community leaders.

In the next section, we will build on the discussion so far, aiming to develop hypotheses that can be used to examine the factors that motivate young entrepreneurs to take action.

\subsection{Social Capital and Community Success}

It has been argued that social capital nurtured in a local community can be the basis for the sustainable development of local businesses (Oe, 2006; 2007; 2010). According to Oe (2006), relationships based on weak bonds can attract new ideas into traditional sectors and promote innovation. They also encourage locals and outsiders to meet on the same platform to discuss the problems they face. On such a platform, the bridging of key actors is essential as a catalyst for the effective functioning of the social network. These key actors can be described as engaging in 'entrepreneurship' (Oe \& Yamaoka, 2020).

Berggren et al. (2006) presented new evidence on how generalised trust is formed, highlighting that trust nurtured among people supports local economies and businesses. Amornsiriphong et al. (2012) argued that social capital is a sufficiency economy and is the foundation for strengthening communities. At the same time, Ansari et al. (2012) state that the role social capital plays in capacity building and community empowerment makes it essential for achieving the positive economic outcome of community revitalisation. Heng et al. (2012) analysed communities in Taiwan and found that a sense of community and good relations between residents were linked to environmentally friendly socio-economic activities. McMurray et al. (2012) also found that building and bridging social capital in fragmented societies are more effective than bonding social capital. Rasmussen et al. (2011) also emphasised that social capital can be used as a means of community change to help bridge different value systems.

Although these arguments provide us with signposts to follow, they do not fully answer the initial question: What is social capital? Although the concept of social capital as facilitating collective action to solve social problems has been established, it usually requires the involvement of some facilitator who can be a catalyst for fostering quality social capital. Whitham (2012) explained that it is crucial first to increase the affection and sense of cohesion among actors in a social network in seeking community success. In other words, only by strengthening the social links and cohesion among actors is it possible to achieve the revitalisation of local communities and the sustainable development of local industries.

From the discussion in the section, the first hypothesis is developed: A sense of community involvement significantly impacts young entrepreneurs' intentions to contribute to local communities and businesses.

\subsection{Emotional Embeddedness and Behaviour}

Biniari (2012) argued that the emotional embeddedness of an entrepreneurial act is a moderator of its social embeddedness. As the sociology of emotions implies, Biniari proposed the study of entrepreneurial effects as an element of the social $\neg-$ emotional interaction between the entrepreneur and others who are influenced by the entrepreneurial process. It has also been found that emotional bonding and goal setting among local stakeholders can enhance collaborative actions and support business sustainability. Kellermanns et al. (2012) extended the socioemotional wealth (SEW) 
perspective by arguing that SEW can negatively associate with proactive stakeholder engagement. They also suggest that SEW dimensions can be associated with positive or negative valence, indicating that excessive emotional bonding can sometimes result in too family-centric behaviour, negatively affecting business performance and engagement. Based on this, bridging social capital should be based on positive and open-minded cohesion that leads to innovation-focused attitudes among stakeholders, helping to tackle issues that should be solved (Oe \& Yamaoka, 2020). Knockaert et al. (2011) argued that conditions for tacit knowledge transfer contribute to the performance of spin-off values and bonding among the relevant stakeholders of local communities, who should share emotional values that can cohere members as a team (Kipkosgei et al., 2020). Breugst et al. (2012) also emphasised how employees' perceptions of entrepreneurial passion influence their commitment to entrepreneurial activities and performance.

From the discussion of the section's theme, the second hypothesis is built: Attachment to the community significantly impacts young entrepreneurs' intentions to contribute to local communities and businesses.

\subsection{Economic vs Non-Economic Value}

Using cognitive data on Japanese small-to-medium-sized enterprise (SME) owners, Oe \& Yamaoka (2020). meticulously investigated the sources of their entrepreneurial behaviour and propose a conceptual model. In particular, they critically examine the applicability of Western-style EO to Japanese entrepreneurs' behaviour. It was found that various factors, such as community attachment and pride in the business, drive their entrepreneurial behaviour. In line with this, we argue that a broader focus on non-economic value rather than economic value alone, as contributing to the mindsets of Japanese entrepreneurs, can lead to long-term sustainable business performance.

Oe \& Yamaoka (2020) also found that the Japanese merchant mentality of SanpoYoshi (the desired result for all three parties: suppliers, customers and society), an old traditional Omi merchant oral discourse, is also embedded in the mindset of today's Japanese SME owners. As mentioned above, we believe that entreprene urial action that considers noneconomic value, rather than focusing solely on economic value, will be effective for creating a sustainable business.

These arguments may apply to the present research. At the same time, quantitative data analysis can help us understand the impacts of economic and non-economic value on the social contributions and business support given by the young generation of entrepreneurs in Mie Prefecture, who are aware of the cultured pearl industry as a familiar local industry. This will act as an effective signpost for the development of robust recommendations that can be applied horizontally to analyse the behaviour of other sectors and different generations of entrepreneurs.

From the discussion of the section's theme, two more hypotheses were developed regarding the economic value and non-economic value as antecedent factors for local young entrepreneurs' willingness to contribute to the local communities and businesses. 


\subsection{Key Takeaways and Analytical Framework}

In the previous sections, a number of implications were extracted from the literature. The keywords and insights that were reflected upon to build hypotheses are as follows. First, social capital should enhance social cohesion among the local residents or potential workforce, which should be formed based on bridging-type rather than bonding-type ties. Second, socialemotional factors, such as affection to the local community or identity, should be carefully analysed. Third, a diverse and open-minded workforce is required to realise an innovative business culture. Finally, the economic outcomes of commercial activity should not be overlooked, even though social values and human relational embeddedness are the centre of the discussion.

To determine the most important factors influencing the potential workforce, especially younger generations among local communities, the following hypotheses were built and confirmed in connection with the main research questions:

Hypothesis 1: A sense of community involvement has a significant impact on young entrepreneurs' intentions to contribute to local communities and businesses.

Hypothesis 2: Attachment to the community has a significant impact on young entrepreneurs' intentions to contribute to local communities and businesses.

Hypothesis 3: Economic value has a significant impact on young entrepreneurs' intentions to contribute to local communities and businesses.

Hypothesis 4: Non-economic value, such as that related to community ties, has a significant impact on young entrepreneurs' intentions to contribute to local communities and businesses.

These four hypotheses encompass the issues identified in light of the literature review. They constitute a framework for examining the various impacts on the willingness of young entrepreneurs to contribute to the revitalisation of their local communities and the sustainable development of local work.

\section{Research Methods}

\subsection{Quantitative Analysis and Survey Design}

This study applies a quantitative approach. The aim is to test and validate a conceptual model containing four hypotheses against a dataset obtained from young entrepreneurs in Japan (Bryman \& Bell, 2015). The study was conducted using a survey to collect data, which is a popular method because it enables the data collection from groups of samples (Saunders et al., 2019; Weathington et al., 2012). As Park \& Park (2016) have discussed, surveys attempt to gather information about an entire group based on a sample. For the survey design, 21 items related to the hypotheses were prepared, with some modification of wording and format following a pilot test carried out on eight volunteers. The questionnaire was initially designed in English, then translated into Japanese, and then translated back to English. The questions were created based on a theoretical framework using a Likert five-point scale (Boari \& Ruscone, 2015).

\subsection{Data Collection and Analysis}

A volunteer group of 170 young entrepreneurs (born between 1985 and 1995) who were living in or were from Mie Prefecture completed the survey. A non-probability quota sampling method was applied, after which convenience sampling and a snowball technique were used to recruit participants for the study (Shukla, 2008). The questionnaire was then 
distributed via email and social network services to a sample of 186 responses. The dataset was reviewed and cleaned for the analysis, and 170 individuals were confirmed as the study sample.

For data analysis, SPSS version 26 was used. Data was analysed based on a descriptive analysis to overview the profile of the dataset, followed by relational analysis using factor analysis with all the relevant observed variables. To test the reliability of the potential factors for further analyses, a Cronbach's alpha test was conducted to validate the factors (McQuitty \& Wolf, 2013; Yamamoto \& Onodera, 1999). Once the variables were confirmed as reliable and suitable for further analysis, a multiple regression analysis was conducted to test the hypotheses.

\section{Discussion}

\subsection{Descriptive and Factor Analysis}

Table 1 shows the outcomes of confirmatory factor analysis to investigate the applicability of Factors 1-4. Using all variables, exploratory factor analysis was conducted to define nine variables for three potential factors: 'attachment to the community, 'economic value', and 'non-economic value' (Table 1). From this process, 18 variables were reduced to 13 based on their explanatory impact on each of the four factors, with the Cronbach's alpha of these factors being sufficiently high (Tavakol \& Dennick, 2011). The selected variables are shown in Table 1, revealing that Factor 1 had four variables in terms of components, Factor 2 had four variables, Factor 3 had three variables, and Factor 4 had two variables. To confirm the composition of each factor, the observed variables, which all had loadings over 0.6, were chosen and examined (Yamamoto \& Onodera, 1999). It was also important for the scale questions to be tested for reliability, and it has previously been suggested that such a scale should be examined based on Cronbach's alpha (Tavakol \& Dennick, 2011). The alpha values of the four latent factors should ideally be over a cut-off level of 0.7 , which indicates significant strength and reliability (Tavakol \& Dennick, 2011).

The alpha test results revealed that 'sense of community involvement' had a value of 0.832 , 'attachment to the community had a value of 0.802 , 'economic value' had a value of 0.724 , and 'non-economic value' had a value of 0.755 . In addition, the Kaiser $\neg-$ Meyer-Olkin measure of sampling adequacy value was 0.828 , which is greater than the accepted threshold of 0.8 (Rusuli et al., 2013). Therefore, the factor analysis indicated that the latent factors explain the dataset and that the results would be reliable. Overall, the total variance explained by the four factors was $57.582 \%$. All these statistical outcomes indicate that the obtained factors, variables, and scales were reasonably designed and sufficiently robust to analyse further. Therefore, we went on to conduct multiple regression analysis using the factor scores. 
Table 1. Factor Analysis and Cronbach's Alpha Results

\begin{tabular}{|c|c|c|c|c|c|}
\hline \multirow[b]{2}{*}{ Questionnaire } & \multicolumn{4}{|c|}{ Component } & \multirow[b]{2}{*}{ Alpha } \\
\hline & 1 & 2 & 3 & 4 & \\
\hline Sense of community involvement 1 & 0.788 & 0.208 & -0.073 & 0.000 & \\
\hline Sense of community involvement 2 & 0.788 & 0.160 & -0.066 & 0.065 & \\
\hline Sense of community involvement 3 & 0.786 & 0.094 & 0.148 & 0.088 & 0.832 \\
\hline Sense of community involvement 4 & 0.750 & 0.168 & 0.153 & 0.110 & \\
\hline Attachment to community 1 & 0.128 & 0.789 & 0.068 & 0.092 & \\
\hline Attachment to community 2 & 0.123 & 0.752 & 0.187 & 0.149 & \\
\hline Attachment to community 3 & 0.060 & 0.727 & 0.036 & -0.046 & 0.802 \\
\hline Attachment to community 4 & 0.291 & 0.717 & 0.122 & 0.238 & \\
\hline Economic value 1 & 0.182 & 0.053 & 0.740 & 0.234 & \\
\hline Economic value 2 & 0.031 & 0.034 & 0.682 & -0.141 & 0.724 \\
\hline Economic value 3 & 0.057 & 0.177 & 0.614 & -0.220 & \\
\hline Non-economic value 1 & 0.142 & 0.207 & -0.136 & 0.782 & \\
\hline Non-economic value 2 & 0.112 & 0.076 & -0.043 & 0.766 & 0.755 \\
\hline
\end{tabular}

\subsection{Regression Analysis}

Table 2 shows the results of the forced imputation regression using the four factor scores to estimate the participants' willingness to contribute to communities. At 0.672 , the adjusted R-squared was sufficiently large, and the Durbin-Watson value was 2.215, which is close to 2, satisfying the conditions for multiple regression analysis. In the variance (ANOVA) test analysis, the significance was 0.000 , which is well below $5 \%$. Thus, these results also indicate robustness (Table 3).

Table 2. Regression Model Summary

\begin{tabular}{|c|c|c|c|c|}
\hline $\mathrm{R}$ & R Square & $\begin{array}{l}\text { Adjusted R } \\
\text { Square }\end{array}$ & $\begin{array}{l}\text { Std. Error of the } \\
\text { Estimate }\end{array}$ & Durbin-Watson \\
\hline 0.825 & 0.680 & 0.672 & 0.645 & 2.215 \\
\hline
\end{tabular}

Dependent Variable: I want to make a contribution for my hometown area.

Table 3. Analysis of Variance

\begin{tabular}{|c|c|c|c|c|c|c|}
\hline & Sum of Squares & $\mathrm{df}$ & & Mean Square & $\mathrm{F}$ & Sig. \\
\hline Regression & 138.781 & & 4 & 34.695 & 83.482 & 0.000 \\
\hline Residual & 65.250 & & 157 & 0.416 & & \\
\hline Total & 204.031 & & 161 & & & \\
\hline
\end{tabular}

Dependent Variable: I want to make a contribution for my hometown area. 
Table 4 shows the coefficients of the regression analysis. It can be seen that the significance of 'factor score 3' was more than 5\%, meaning it had to be neglected. Finally, the results of the derived multiple regression equation are shown below (Eq. 1). Factor 1, 'sense of community involvement'; Factor 2, 'attachment to the community'; and Factor 4, 'noneconomic value', were found to be significant in estimating the particpants' willingness to contribute to their communities, while Factor 3, 'economic value', was found not to be significant.

dependent variable $=3.623+(0.802 *$ factor score 1$)+(0.439 *$ factor score 2$)+(0.150 *$ factor score 4)

Table 4. Coefficients of Regression Analysis

\begin{tabular}{lccccc}
\hline & $\begin{array}{c}\text { Unstandardize } \\
\text { d Coefficients }\end{array}$ & \multicolumn{2}{c}{$\begin{array}{c}\text { Standardized } \\
\text { Coefficients } \\
\text { Beta }\end{array}$} & t & Sig. \\
\hline B Constant) & 3.623 & 0.051 & & 71.539 & 0.000 \\
factor score 1 & 0.802 & 0.051 & 0.713 & 15.790 & 0.000 \\
factor score 2 & 0.439 & 0.051 & 0.390 & 8.638 & 0.000 \\
factor score 3 & 0.057 & 0.051 & 0.050 & 1.119 & 0.265 \\
factor score 4 & 0.150 & 0.051 & 0.133 & 2.954 & 0.004 \\
\hline
\end{tabular}

Overall, the survey data analysis results confirm that the mindset of young entrepreneurs regarding the proposition of revitalising local communities and supporting local industry can be explained by four factors extracted from previous literature. The investigation of these four factors confirms that economic and non-economic value should be recognised as a principle of behaviour. Among these four factors, this study confirmed that Factors 1 and 2, which represented elements related to community ties (as proposed by the social capital theory), positively impacted the respondents' willingness to contribute.

The results of multiple regression analysis using the factor scores obtained from the factor analysis as explanatory variables revealed that, of the above four factors, the first factor, 'sense of community involvement; the second factor, 'attachment to the community; and the fourth factor, 'non-economic value, such as that related to community ties', each had a significant impact on the respondents' willingness to contribute to the community. Only the third factor, 'economic value', did not have a significant impact.

The results obtained here support the qualitative research findings of Oe \& Yamaoka (2020) with quantitative results, and we hope that further confirmation and in-depth testing of these results will provide a clear and practical model and guidelines for the revitalisation of local communities in Japan.

\section{Conclusion}

\subsection{Contributions}

The conclusions of this study represent a significant contribution to the field of research in two ways. First, the study presents a useful analytical tool for deciphering the attitudes of young entrepreneurs when confronted with the proposition of revitalising local communities and supporting local industry. This analytical tool can be applied to sustainable 
society building in various contexts as an easy-to-use model that is simple to implement and contributes to the promotion of empirical analysis in the field of social economy.

Second, the results obtained here, especially the conclusion that, of the four examined factors, only 'economic value' does not significantly impact the behaviour of young entrepreneurs, will be of use in the future. In particular, they can be turned to the question of determining the context that should be brought about to stimulate the motivation and action of young entrepreneurs who want to invest their wisdom and energy in supporting local communities and industries. The conclusion that young entrepreneurs are motivated to take action in support of their communities and local industries provides a clear hint as to the context in which to motivate and inspire them to action. This second finding also supports the findings of Oe \& Yamaoka (2020). It provides a practical scheme for expanding the scope of this study to include Mie Prefecture and incorporating the contributions of entrepreneurs in solving socio-economic problems in various industries and regions.

\subsection{Limitations and Further Research Opportunities}

As mentioned in the previous section, this study provides significant contributions, both theoretically and practically. However, we are well aware that the results obtained here require further in-depth study and validation before generalising. This is especially true given the limited number of data sets available for analysis and the fact that the project participants in question responded to themes related to specific regions and projects.

In order to surpass this limitation and expand the implications of this study to contribute more to the research in the field, we have established the following plans for future research. First, we will attempt to expand the analytical model proposed in this study by collecting and analysing data on community revitalisation and local industry growth in different regions in Japan, using a similar method. The analysis will be supplemented not only by quantitative approaches but also with qualitative methods, such as interviews and focus groups, so as to capture the phases of entrepreneur consciousness more closely. Further, to develop a more sophisticated model of Japanese entrepreneurial behaviour that does not rely solely on 'economic value', we aim to extract the factors that stimulate entrepreneurial behaviour and refine our analytical model. The model will then be used for international comparisons, and policy implications regarding the active commitments and contributions of local stakeholders to the revitalisation of communities struggling with economic and social problems will be identified and discussed.

\section{References}

Ansari, S., Munir, K. \& Gregg, T. (2012). Impact at the 'Bottom of the Pyramid': The Role of Social Capital in Capability Development and Community Empowerment. Journal of Management Studies, 49(4), 813-842.

Amornsiriphong, S., Piemyat, S. \& Charoenrat, O. (2012). Social capital: Foundation to strengthen the sufficiency economy communities. Procedia Engineering, 32, 1147 1151.

Berggren, N. \& H. Jordahl (2006). Free to Trust: Economic Freedom and Social Capital. Kyklos, 59(2), 141-169.

Biniari, M. G. (2012). The Emotional Embeddedness of Corporate Entrepreneurship: The Case of Envy. Entrepreneurship Theory \& Practice, 36 (1), 141-170.

Boari, G., \& Nai Ruscone, M. (2015). A procedure simulating Likert scale item responses. Electronic journal of applied statistical analysis, 8(3), 288-297. 
Breugst, N., Domurath, A., Patzelt, H. \& Klaukien, A. (2012). Perceptions of Entrepreneurial Passion and Employees' Commitment to Entrepreneurial Ventures. Entrepreneurship Theory \& Practice, 36(1), 171-192.

Bryman, A. \& Bell, E. (2015). Business Research Methods. Fourth edition. Oxford: Oxford University Press

Eddleston, K. A., Kellermanns, F. W. \& Zellweger, T. M. (2012). Exploring the Entrepreneurial Behavior of Family Firms: Does the Stewardship Perspective Explain Differences?. Entrepreneurship Theory \& Practice, 36(2), 347-367.

Fini, R., Grimaldi, R., Marzocchi, G. L. \& Sobrero, M. (2012). The Determinants of Corporate Entrepreneurial Intention Within Small and Newly Established Firms. Entrepreneurship Theory \& Practice, 36(2), 387-414.

Gemmell, R. M., Boland, R. J. \& Kolb, D. A. (2012). The Socio-Cognitive Dynamics of Entrepreneurial Ideation. Entrepreneurship Theory \& Practice, 36(5), 1053-1073.

Haynie, J. M., Shepherd, D. A. \& Patzelt, H. (2012). Cognitive Adaptability and an Entrepreneurial Task: The Role of Metacognitive Ability and Feedback. Entrepreneurship Theory \& Practice, 36(2), 237-265.

Heng, Z. \& Shih-Hsien, L. (2012). Sense of Community in Taiwan and its Relationships with the Residential Environment. Procedia - Social and Behavioral Sciences, 35, 335-343.

Japan Fisheries Agency (2017). Fishery Agency Facilities Information Magazine, Window on Fishery Management, July 2017. available at: https://www.jfa.maff.go.jp/j/koho/pr/mado/attach/pdf/index-13.pdf [accessed 25 May 2021]

Kellermanns, F. W., Eddleston, K. A. \& Zellweger, T. M. (2012). Extending the Socioemotional Wealth Perspective: A Look at the Dark Side. Entrepreneurship Theory \& Practice, 36(6), 1175-1182.

Kipkosgei, F., Kang, S. W. \& Choi, S. B. (2020). A team-level study of the relationship between knowledge sharing and trust in Kenya: Moderating role of collaborative technology. Sustainability, 12(4), 1615.

Knockaert, M., Ucbasaran, D., Wright, M. \& Clarysse, B. (2011). The Relationship Between Knowledge Transfer, Top Management Team Composition, and Performance: The Case of Science-Based Entrepreneurial Firms. Entrepreneurship Theory \& Practice, 35(4), 777-803.

Kreiser, P. M. (2011). Entrepreneurial Orientation and Organizational Learning: The Impact of Network Range and Network Closure. Entrepreneurship Theory \& Practice, 35(5), 1025-1050.

Lordkipanidze, M., Brezet, H. \& Backman, M. (2005). The entrepreneurship factor in sustainable tourism development. Journal of Cleaner Production, 13(8), 787-798.

McMurray, A. \& Niens, U. (2012). Building Bridging Social Capital in a Divided Society: The Role of Participatory Citizenship Education. Education, Citizenship and Social Justice, 7(2), 207-221.

Mcquitty, S. \& Wolf, M. (2013). Structural Equation Modeling: A Practical Introduction. Journal of African Business, 14(1), 58-69.

Morris, M. H., Kuratko, D. F., Schindehutte, M. \& Spivack, A. J. (2012). Framing the Entrepreneurial Experience. Entrepreneurship Theory \& Practice, 36(1), 11 -40.

Oe, H. \& Weeks, M. (2020). Kawaii culture in Japan: A bibliometric analysis and text mining approach based on pop-cultural diplomacy and transmission into global values. Budapest International Research and Critics Institute (BIRCI-Journal): Humanities and Social Sciences, 3 (4), 3990-4004.

Oe, H. \& Yamaoka, Y. (2013). Entrepreneurship, Leadership and Communication: A Case Study of Cultured Pearl Industry in Japan. In British Academy of Management, September 2013, Liverpool, UK. 
Oe, H. \& Yamaoka, Y. (2020). How to enhance sustainability goals implementation in the business behavior: A lesson from the discussions of Japanese Small and Medium-sized Enterprises. Social Business, 10 (3), 281-304.

Park, J. \& Park, M. (2016). Qualitative versus quantitative research methods: discovery or justification?. Journal of Marketing Thought, 3 (1), 1-7.

Rasmussen, C. M., Armstrong, J. \& Chazdon, S. A. (2011). Bridging Brown County: Captivating Social Capital as a Means to Community Change. Journal of Leadership Education, 10(1), 63-82.

Rusuli, C. M., Tasmin, R., Takala, J. \& Norazlin, H. (2013). Factor retention decisions in exploratory factor analysis results: A study type of knowledge management process at Malaysian university libraries. Asian Social Science, 9(15), 227.

Saunders, M., Lewis, P. \& Thornhill, A. (2019). Research Methods for Business students. (8th ed) Harlow.

Shukla, P. (2008). Marketing Research. Ventus Publishing ApS, Copenhagen.

Tavakol, M. and Dennick, R., (2011). Making sense of Cronbach's alpha. International Journal of Medical Education, 2, 53-55.

Weathington, B. L., Cunningham, C.J. \& Pittenger, D.J. (2012). Understanding Business Research. New Jersey: John Wiley \& Sons Inc.

Whitham, M. M. (2012). Community Connections: Social Capital and Community. Sociological Forum, 27(2), 441-457.

Yamamoto, K. \& Onodera, T. (1999). Structural Equation Modelling by Amos and case analyses. Kyoto: Nakanishiya Syuppan. 